\title{
Woody vegetation response to various burning regimes in South Texas
}

\author{
DONALD C. RUTHVEN III, ANTHONY W. BRADEN, HALEY J. KNUTSON, JAMES F. GALLAGHER, AND \\ DAVID R. SYNATZSKE
}

Authors are Natural Resource Specialist (DCR, JFG), Research Assistants (AWB, HJK), and Area Manager (DRS), Chaparral Wildlife Management Area, Texas Parks and Wildlife Department, Artesia Wells, Tex. 78001.

\begin{abstract}
Responses of woody plant communities on native rangelands in the western South Texas Plains to fire are not clearly understood. Our objective was to compare woody plant cover, density, and diversity on burned and nontreated rangelands. Five rangeland sites that received 2 dormant-season burns, 5 rangeland sites that received a combination of 1 dormant-season and 1 growing-season burn, and 5 sites of nontreated rangeland were selected on the Chaparral Wildlife Management Area, Dimmit and La Salle Counties, Tex. Woody plant cover was estimated using the line intercept method, and stem density was estimated in $25-\mathrm{x} 1.5-\mathrm{m}$ plots. Species richness did not differ among treatments. Percent woody plant cover was reduced by 50 and $41 \%$ on winter and winter-summer combination burned sites, respectively. Honey mesquite (Prosopis glandulosa Torr.), twisted acacia (Acacia schaffneri S. Wats.), Texas persimmon (Diospyros texana Scheele), lotebush [Ziziphus obtusifolia (Hook.) T. \& G.], wolfberry (Lycium berlandieri Dunal), and tasajillo (Opuntia leptocaulis Cand.) canopy cover was greatest on nontreated sites. Woody plant density declined by 29 and $23 \%$ on winter and winter-summer combination burned sites, respectively. Density of guayacan (Guajacum angustifolium Engelm.), wolfberry, and tasajillo was less on all burning treatments. Percent cover of spiny hackberry (Celtis pallida Torr.) and density of Texas pricklypear (Opuntia engelmannii Salm-Reif.-Dyck) declined on winter burned sites. Inclusion of summer fire into the burning regime did not increase declines in woody plants. Fire created a post-fire environment which resulted in the decline of many woody plant species. It is unclear to what degree other environmental factors such as herbivory and competition between woody plants and among woody and herbaceous vegetation may have interacted with fire in producing woody plant declines. Fire may be a useful tool in managing woody vegetation on native south Texas rangelands, while maintaining woody plant diversity.
\end{abstract}

Key Words: fire, diversity, range improvement, wildlife habitat.

The Rio Grande Plains of South Texas is the southern most extension of the Great Plains Grasslands. Fire, along with other climatic variables such as drought presumably maintained the mesquite (Prosopis glandulosa Torr.) savannas and interspersed grasslands of pre-European settlement South Texas (Scifres and Hamilton 1993). Frequency of fire appeared to be highly variable

Manuscript accepted 14 Jun. 02.

\section{Resumen}

La respuesta de las comunidades arbustivo-leñosas de los terrenos de pastizal de las planicies del suroeste de Texas al fuego prescrito no ha podido ser entendida claramente. El objetivo de este estudio fué comparar la cobertura, densidad, y diversidad de plantas arbustivo-leñosas en áreas tratadas con fuego prescrito y en áreas no tratadas. Quince sitios fueron seleccionados en el Area de Manejo de Fauna Silvestre Chaparral ubicada en los condados de Dimmit y La Salle en Tex.: 5 sitios recibieron fuego prescrito en 2 ocaciones, ambas durante la estación de dormancia (invierno); otros 5 sitios recibieron fuego prescrito en 2 ocasiones, una vez durante la estación de dormancia y otra durante la estación de crecimiento activo (verano); y 5 sitios no recibieron tratamiento. La cobertura de plantas arbustivoleñosas se estimó por medio del método de intercepción de linea, y la densidad de área basal se estimó usando parcelas de 25 x 1.5m. El parámetro de riqueza de especies fué similar entre tratamientos. El porcentaje de cobertura de plantas arbustivoleñosas se redujo en $50 \%$ en los sitios tratados en el invierno y en $41 \%$ y en los sitios tratados en invierno y verano. La cobertura del dosel de especies como Prosopis glandulosa Torr., Acacia schaffneri S. Wats., Diospyros texana Scheele, Ziziphus obtusifolia (Hook.) T. \& G., Lycium berlandieri Dunal, y Opuntia leptocaulis Cand. fué mayor en sitios no tratados. La densidad de plantas arbustivas se redujo en $29 \%$ en los sitios tratados en el invierno y en $23 \%$ en los sitios tratados en invierno y verano. La densidad de Guajacum angustifolium Engelm., Lycium berlandieri Dunal, y Opuntia leptocaulis Cand. fué menor en todos los sitios que recibieron tratamiento. El porcentaje de cobertura de Celtis pallida Torr. y la densidad de Opuntia engelmannii Salm-Reif.-Dyck se redujo en los sitios tratados durante el invierno. La aplicación de fuego prescrito durante el verano no contribuyó a la reducción del núnero de especies arbustivas. El ambiente creado por el fuego después de su aplicación, resultó en la reducción de muchas especies arbustivas. El grado de interacción entre el fuego prescrito y otros factores ambientales, como los herbívoros, la competencia entre plantas arbustivas y entre plantas arbustivas y vegetación herbacea, en la reducción de plantas arbustivas, no es del todo claro. El fuego prescrito pudiera ser una herramienta muy útil en el manejo de la vegetación arbustivo-leñosa de los pastizales nativos del sur de Texas, y en el mantenimiento de su diversidad.

and ranged from 5-30 years (Wright and Bailey 1982). Following European settlement, suppression of fire combined with heavy livestock grazing lead to the current thorn woodlands common 
throughout South Texas (Archer et al. 1988, Archer 1994).

Beginning in the mid-twentieth century, South Texas landowners began to convert thorn woodlands back to grasslands to enhance rangelands for livestock production. Mechanical treatments such as root plowing were commonly used to achieve this goal. However, once treated rangelands are revegetated by woody species, woody plant diversity can be greatly reduced (Fulbright and Beasom 1987, Ruthven et al. 1993). In South Texas, woody plants are a primary component of white-tailed deer (Odocoileus virginianus Boddaert) diet (Arnold and Drawe 1979, Taylor et al. 1997). Woody plants are also an important cover source for northern bobwhite (Colinus virginianus L.) (Guthrey 1986), and woody plants provide escape cover and thermal refugia to species of concern such as the Texas tortoise (Gopherus berlandieri Stejneger) (Kazamier 2000) and Texas horned lizard (Phrynosoma cornutum Gray) (Burrow et al. 2001).

Land ownership and land use practices in South Texas have changed in recent years. The size of individual landholdings has decreased and revenue derived from ranch properties has become increasingly dependent on wildlife rather than traditional livestock operations (Wilkins et al. 2000). Fall and winter burning along the transition zone between the South Texas Plains and Gulf Prairies and Marshes can reduce brush cover while maintaining woody plant diversity (Box and White 1969) and increase herbaceous vegetation preferred by wildlife (Box and White 1969, Hansmire et al. 1988). Fire can also provide an economical means of controlling woody species and maintaining the life of mechanical and chemical brush management treatments (Scifres and Hamilton 1993). Burning during late winter and early spring is recommended for achieving many goals on South Texas rangelands (Scifres and Hamilton 1993). As a result of reported benefits, South Texas rangeland managers are beginning to utilize fire to enhance wildlife habitat; yet, little information is available on the response of vegetation to fire in the more xeric areas of the western Rio Grande Plains. Concerns have arisen that dormantseason fire may adversely affect species of concern such as the Texas horned lizard, which hibernate at shallow depths in South Texas (Fair and Henke 1997) and that burning during summer when species such as the Texas horned lizard are active may reduce direct mortality. Summer wildfire can severely damage woody plants (Cable 1965), suggesting that controlled growing-season fire may provide an effective means of managing woody vegetation. Data on the effects of summer fire on vegetation and wildlife in South Texas are lacking.

Our objective was to determine the effects of combinations of dormant and growing-season fire on woody plant diversity, canopy cover, and density on native rangelands in the western South Texas Plains. We hypothesize that prescribe burning these South Texas rangelands will reduce woody cover while maintaining woody plant densities and diversity and that incorporation of summer fire will result in increased reductions of woody plants.

\section{Materials and Methods}

The study area was on the Chaparral Wildlife Management Area (28 $28^{\prime} \mathrm{N}$, $\left.99^{\circ} 25^{\prime} \mathrm{W}\right)$ in the western South Texas Plains. The study area was purchased by the state of Texas in 1969, and is managed by the Wildlife Division of the Texas Parks and Wildlife Department (TPWD). Climate is characterized by hot summers and mild winters with an average daily minimum winter (January) temperature of $5^{\circ} \mathrm{C}$, an average daily maximum summer (July) temperature of $37^{\circ} \mathrm{C}$, and a growing season of 249 to 365 days depending on freezing temperatures (Stevens and Arriaga 1985). Precipitation pattern is bimodal with peaks occurring in late spring (May-June) and early fall (September-October). The 11-year (19892000) average precipitation amount is 54 cm (TPWD, unpubl. data).

Treatments consisted of 2 winter prescribed burns (winter burn), a winter burn followed by a summer fire (winter-summer burn), and nontreated rangeland sites. Each treatment was replicated 5 times and arranged in a randomized block design. All study plots were about 2-ha in size. Study plots were interspersed among 4 pastures in the central portion of the study area and each plot separated by $>500-\mathrm{m}$. Pretreatment sampling was not conducted; however, total woody plant canopy cover and composition of dominant woody species was considered similar among study plots prior to application of burning treatments (Gabor 1997). Burned plots were located within larger (> 50-ha) areas that were burned. Study plots and surrounding rangeland subjected to fire were burned simultaneously during each burn- ing application. All study plots received $100 \%$ coverage by burns. All burned plots were subjected to fire during winter (December-March) 1997-1998. Winter burn plots were again burned in winter (November-January) 1999-2000. A summer fire was applied to winter-summer burn plots in August 1999. Relative humidity and air temperature, using a sling psychrometer, and surface wind speed, using the Bufort Scale, were estimated before ignition and at the completion of each fire. Relative humidity was $21 \pm 3 \%$ $(\overline{\mathrm{x}} \pm \mathrm{SE}), 20 \pm 1 \%$, and $32 \pm 0 \%$, temperature was $23 \pm 2^{\circ} \mathrm{C}, 22 \pm 3^{\circ} \mathrm{C}$, and $39 \pm 0^{\circ}$ $\mathrm{C}$, and wind speed was $13 \pm 2 \mathrm{kph}, 10 \pm 2$ $\mathrm{kph}$, and $8 \pm 0 \mathrm{kph}$ for 1997-1998 winter burns, 1999-2000 winter burn applications, and 1999 summer burns, respectively. Relative humidity and air temperature during winter fires followed recommended prescriptions for the vegetation type present (Wright and Bailey 1982), while wind speed was slightly below recommended parameters. Little prescription data is available for summer burning in South Texas; however, $35^{\circ} \mathrm{C}$ is generally considered the upper limit for most prescribed burning (Wright and Bailey 1982). In South Texas, adequate humidity levels for burning are generally not reached until air temperatures are in excess of the recommended maximum. Wind direction was variable. Soil moisture was not recorded. No significant $(>0.4-\mathrm{cm})$ precipitation events were recorded within a 30-day period prior to winter burns and we considered soil moisture low. Summer burns were conducted 3 to 5 days following a $23-\mathrm{cm}$ rainfall event and soil moisture was considered high. Summer burns were conducted under moist soil conditions because summer burning with little soil moisture can result in significant mortality of perennial grasses (Scifres and Duncan 1982). Because of variable wind speed and direction during all burns and uneven fuel loads, fire behavior was highly variable and not recorded. Fuel loads appeared to vary within study plots. Previous work on the study site in which fuel loads were estimated by clipping above ground biomass indicate that adequate fuel loads for burning in western portions of South Texas are $\geq 2,000 \mathrm{~kg} / \mathrm{ha}$ (TPWD, unpubl. data). Based on our visual estimations, fuel loads on study plots met adequate levels. All burns were ignited as head fires with drip torches.

Soils were similar among treatments and consisted of Duval fine sandy loam, gently undulating, Duval loamy fine sand, 0-5\% slopes, and Dilley fine sandy loam, gently 
undulating (Stevens and Arriaga 1985, Gabriel et al. 1994). The Duval series are fine-loamy, mixed, hyperthermic Aridic Haplustalfs and the Dilley series are loamy, mixed, hyperthermic shallow Ustalfic Haplargids. Topography is nearly level to gently sloping and elevation ranges between 168 and 180-m.

Vegetation is characterized by a twophase pattern of shrub clusters scattered throughout a grassland/savanna (Whittaker et al. 1979, Archer et al. 1988). Plant communities belonged to the Honey mesquiteSpiny hackberry (Celtis pallida Torr.) association (McLendon 1991). Within this association were 2 primary communities, the Honey mesquite-Lime pricklyash [Zanthoxylum fagara (L.) Sarg.]/Spiny hackberry community, in which lime pricklyash and brasil (Condalia hookeri $\mathrm{M}$. C. Johnst.) are the subdominants, and the Honey mesquite-Spiny hackberry/Hogplum (Colubrina texana T. \& G.) community, in which hog-plum is the subdominant. Prominent herbaceous species included Lehmann lovegrass (Eragrostis lehmanniana Nees), an introduced perennial, hooded windmillgrass (Chloris cucullata Bisch.), hairy grama (Bouteloua hirsuta Lag.), partridge pea [Chamaecrista fasciculata (Michx.) Greene], and croton (Croton spp. L.).

No record exists of the study plots being burned before the application of fire during winter 1997-1998. Domestic livestock have grazed the study area since the $18^{\text {th }}$ century (Lehmann 1969). Cattle have been the major species of livestock since about 1870 , whereas sheep were grazed from about 1750 to 1870 . Grazing strategies on the study area have varied from continuous grazing to various rotational grazing systems (Ruthven et al. 2000). Since 1990, including the timeframe of this study, the study area has been grazed using stocker cattle under a high intensity, low frequency grazing system during the period October through April. Stocking rate was 25 animal-unit days ha $^{-1}$ year ${ }^{-1}$.

Three, north to south oriented, $100-\mathrm{m}$ transects, were uniformly distributed on each study plot. Ten, 25-m lines were placed at $10-\mathrm{m}$ intervals along each transect. Lines were oriented perpendicular to transects and direction of each line was randomly chosen by coin flip. Woody plant canopy cover was estimated during late spring and early summer 2001 by the line-intercept method (Canfield 1941). Woody plant density was estimated by counting stems in $25-\mathrm{x} 1.5-\mathrm{m}$ plots placed along each 25-m line. Frequency of occurrence of individual species was also esti- mated in $25-\mathrm{x} 1.5-\mathrm{m}$ plots and used to estimate species richness, diversity, and evenness. Woody species diversity (H') and evenness ( $\left.\mathbf{J}^{\prime}\right)$ was quantified with Shannon's Index (Pielou 1975). Because of their woody growth form in South Texas, succulents such as pricklypear (Opuntia spp. Miller) and suffrutescents including lantana (Lantana spp. L.) were considered woody plants in this study. Scientific names of Texas plants follow Jones et al. (1997) and common names are from Hatch et al. (1990).

Percent canopy cover, density, and frequency of occurrence of woody species were evaluated at the transect level using multivariate analysis of variance (MANO$\mathrm{VA}$ ), with treatment as the main effect. Two-treatment comparisons were not conducted due to limited sample size. Tukey's

Table 1. Mean woody plant canopy cover $(\%)$ on winter burned ${ }^{1}$, winter-summer burned ${ }^{2}$, and nonburned sites $^{3}$ on the Chaparral Wildlife Management Area, Dimmit and La Salle Counties, Tex. 2001.

\begin{tabular}{|c|c|c|c|}
\hline Species & Winter burn & Winter-summer burn & Nonburned \\
\hline & & $--(\%)-$ & - . . - \\
\hline Guajillo & $0.2 \mathrm{a}^{4}$ & $0 \mathrm{a}$ & $0 \mathrm{a}$ \\
\hline Catclaw Acacia & $1.0 \mathrm{a}$ & $0.1 \mathrm{a}$ & $0.3 \mathrm{a}$ \\
\hline Huisache & $<0.1 \mathrm{a}$ & $<0.1 \mathrm{a}$ & $0.1 \mathrm{a}$ \\
\hline Blackbrush & $0.4 \mathrm{a}$ & $0 \mathrm{a}$ & $0 \mathrm{a}$ \\
\hline Twisted Acacia & $1.3 \mathrm{a}$ & $0.7 \mathrm{a}$ & $2.7 \mathrm{~b}$ \\
\hline Whitebrush & $0.1 \mathrm{a}$ & $<0.1 \mathrm{a}$ & $0.6 \mathrm{a}$ \\
\hline Goatbush & $0 \mathrm{a}$ & $0 \mathrm{a}$ & $<0.1 \mathrm{a}$ \\
\hline Sugar Hackberry & $0 \mathrm{a}$ & $0 \mathrm{a}$ & $<0.1 \mathrm{a}$ \\
\hline Spiny Hackberry & $0.6 \mathrm{a}$ & $1.9 \mathrm{~b}$ & 2.2 \\
\hline Hog-plum & $6.1 \mathrm{a}$ & $7.1 \mathrm{a}$ & 9.5 \\
\hline Brasil & $3.1 \mathrm{a}$ & $3.6 \mathrm{a}$ & $3.9 \mathrm{a}$ \\
\hline Texas Persimmon & $0.7 \mathrm{a}$ & $1.4 \mathrm{ab}$ & $2.5 \mathrm{~b}$ \\
\hline Vine Ephedra & $0 \mathrm{a}$ & $0 \mathrm{a}$ & $0 \mathrm{a}$ \\
\hline Narrowleaf Forestiera & $0.2 \mathrm{ab}$ & $0 \mathrm{a}$ & $0.6 \mathrm{~b}$ \\
\hline Guayacan & $0.1 \mathrm{a}$ & $0.1 \mathrm{ab}$ & $0.5 \mathrm{~b}$ \\
\hline Tatalencho & 0a & $<0.1 \mathrm{a}$ & $<0.1 \mathrm{a}$ \\
\hline Leatherstem & $0 \mathrm{a}$ & $<0.1 \mathrm{a}$ & $0.2 \mathrm{a}$ \\
\hline Coyotillo & $0.8 \mathrm{a}$ & $0.2 \mathrm{a}$ & $1.0 \mathrm{a}$ \\
\hline Veinyleaf Lantana & $0.1 \mathrm{a}$ & $0 \mathrm{a}$ & $0 \mathrm{a}$ \\
\hline Common Lantana & $1.6 \mathrm{a}$ & $3.5 \mathrm{a}$ & $2.5 \mathrm{a}$ \\
\hline Wolfberry & $0.2 \mathrm{a}$ & $0.1 \mathrm{a}$ & $0.9 \mathrm{~b}$ \\
\hline Texas Pricklypear & $1.1 \mathrm{a}$ & $1.7 \mathrm{a}$ & $2.0 \mathrm{a}$ \\
\hline Tasajillo & $0.1 \mathrm{a}$ & $0.2 \mathrm{a}$ & $1.2 \mathrm{~b}$ \\
\hline Honey Mesquite & $3.8 \mathrm{a}$ & $5.5 \mathrm{a}$ & $11.5 \mathrm{~b}$ \\
\hline Little-leaf Sumac & $0.1 \mathrm{a}$ & $0 \mathrm{a}$ & $0 \mathrm{a}$ \\
\hline Desert Yaupon & $0.1 \mathrm{a}$ & $0.1 \mathrm{a}$ & $0.4 \mathrm{~b}$ \\
\hline Coma & $<0.1 \mathrm{a}$ & $<0.1 \mathrm{a}$ & $0.3 b$ \\
\hline Lime Pricklyash & $0.6 \mathrm{a}$ & $<0.1 b$ & $0.1 \mathrm{~b}$ \\
\hline Lotebush & $<0.1 \mathrm{a}$ & $0.1 \mathrm{a}$ & 0.7 \\
\hline Total canopy coverage ${ }^{5}$ & $22 \mathrm{a}$ & $26 \mathrm{a}$ & $44 \mathrm{~b}$ \\
\hline
\end{tabular}

${ }_{2}^{1}$ Sites burned during winter 1997-1998 and winter 1999-2000

${ }_{3}^{2}$ Sites burned during winter 1997-1998 and summer 1999.

$3 \mathrm{n}=15$ transects/site/treatment.

${ }_{5}^{4}$ Cover values for a species across treatments followed by the same letter are not significantly different $(\mathrm{P}>0.05)$.

$5 \mathrm{n}=5$ sites/treatment.
HSD was used to compare individual treatments where univariate tests indicated significant $(\mathrm{P}<0.05)$ treatment effects on individual species. Total woody plant canopy cover and total stem density, as well as species richness and Shannon's index of species diversity and evenness were calculated at the treatment level and analyzed by a 1-way analysis of variance (ANOVA) with treatment as the main effect. Tukey's HSD was used to compare treatment means. Treatment differences were considered significant at the $\mathrm{P}<0.05$ level.

\section{Results}

Shannon's index of species diversity varied $(P=0.0267)$ among treatments. 
Table 2. Mean woody plant density (stems/ha) on winter burned ${ }^{1}$, winter-summer burned ${ }^{2}$, and nonburned sites $^{3}$ on the Chaparral Wildlife Management Area, Dimmit and La Salle Counties, Tex. 2001.

\begin{tabular}{|c|c|c|c|}
\hline Species & Winter burn & Winter-summer burn & Nonburned \\
\hline & & - - (stems/ha) - - & \\
\hline Guajillo & $2 a^{4}$ & $0 \mathrm{a}$ & $0 \mathrm{a}$ \\
\hline Catclaw Acacia & $121 \mathrm{a}$ & $25 \mathrm{a}$ & $36 \mathrm{a}$ \\
\hline Huisache & $2 \mathrm{a}$ & $0 \mathrm{a}$ & $5 \mathrm{a}$ \\
\hline Blackbrush & $16 \mathrm{a}$ & $0 \mathrm{a}$ & $0 \mathrm{a}$ \\
\hline Twisted Acacia & $178 \mathrm{a}$ & $94 \mathrm{a}$ & $204 a$ \\
\hline Whitebrush & $14 \mathrm{a}$ & $0 \mathrm{~b}$ & $94 a$ \\
\hline Goatbush & $0 \mathrm{a}$ & $0 \mathrm{a}$ & $11 \mathrm{a}$ \\
\hline Sugar Hackberry & $0 \mathrm{a}$ & $0 \mathrm{a}$ & $2 \mathrm{a}$ \\
\hline Spiny Hackberry & $116 \mathrm{a}$ & $140 \mathrm{ab}$ & $208 \mathrm{~b}$ \\
\hline Hog-plum & $731 \mathrm{a}$ & $665 \mathrm{a}$ & $526 \mathrm{a}$ \\
\hline Brasil & $128 \mathrm{a}$ & $87 a$ & $128 \mathrm{a}$ \\
\hline Texas Persimmon & $67 a$ & $113 a$ & $194 a$ \\
\hline Vine Ephedra & $0 \mathrm{a}$ & $5 \mathrm{a}$ & $2 \mathrm{a}$ \\
\hline Narrowleaf Forestiera & $16 a b$ & $0 \mathrm{a}$ & $27 \mathrm{~b}$ \\
\hline Guayacan & $7 \mathrm{a}$ & $7 \mathrm{a}$ & $85 \mathrm{~b}$ \\
\hline Tatalencho & $0 \mathrm{a}$ & $0 \mathrm{a}$ & $0 \mathrm{a}$ \\
\hline Leatherstem & $5 \mathrm{a}$ & $23 \mathrm{a}$ & $119 \mathrm{a}$ \\
\hline Coyotillo & $52 \mathrm{a}$ & $14 \mathrm{a}$ & $50 \mathrm{a}$ \\
\hline Veinyleaf Lantana & $4 a$ & $0 \mathrm{a}$ & $0 \mathrm{a}$ \\
\hline Common Lantana & $485 \mathrm{a}$ & $745 \mathrm{a}$ & $644 a$ \\
\hline Wolfberry & $27 \mathrm{a}$ & $9 \mathrm{a}$ & $82 b$ \\
\hline Texas Pricklypear & $683 a$ & $1,001 \mathrm{ab}$ & $1,095 \mathrm{~b}$ \\
\hline Tasajillo & $23 \mathrm{a}$ & $30 a$ & $187 \mathrm{~b}$ \\
\hline Honey Mesquite & $242 \mathrm{a}$ & $238 \mathrm{a}$ & $304 a$ \\
\hline Little-leaf Sumac & $4 \mathrm{a}$ & $0 \mathrm{a}$ & $2 \mathrm{a}$ \\
\hline Desert Yaupon & $5 \mathrm{a}$ & $12 \mathrm{a}$ & $44 \mathrm{~b}$ \\
\hline Coma & $44 \mathrm{a}$ & $7 \mathrm{a}$ & $21 \mathrm{a}$ \\
\hline Lime Pricklyash & $34 a$ & $2 a$ & $21 \mathrm{a}$ \\
\hline Lotebush & $12 \mathrm{a}$ & $20 \mathrm{a}$ & $53 b$ \\
\hline Total woody plant density ${ }^{5}$ & $3,018 \mathrm{a}$ & $3,237 \mathrm{a}$ & $4,144 b$ \\
\hline
\end{tabular}

${ }^{1}$ Sites burned during winter 1997-1998 and winter 1999-2000.

${ }^{2}$ Sites burned during winter 1997-1998 and summer 1999.

$3 \mathrm{n}=15$ transects/site/treatment.

${ }^{4}$ Cover values for a species across treatments followed by the same letter are not significantly different $(\mathrm{P}>0.05)$.

$5 \mathrm{n}=5$ sites/treatment.

Diversity did not differ between winter $(2.33 \pm 0.13)(\overline{\mathrm{x}} \pm \mathrm{SE})$ and winter-summer $(2.13 \pm 0.09)$ burning treatments whereas diversity on nonburned sites $(2.55 \pm 0.04)$ was greater than winter-summer burned treatments. Species richness and evenness did not differ among winter burned (16 \pm 2 species/treatment, $0.85 \pm 0.02$, respectively), winter-summer burned $(13 \pm 2$, $0.85 \pm 0.01)$, and nonburned $(18 \pm 1,0.88$ \pm 0 ) treatments. Percent woody plant canopy cover differed between treatments (MANOVA $\mathrm{P} \leq 0.0001)$. Percent total woody plant canopy cover was greatest $(\mathrm{P}$ $=0.0002$ ) on nonburned plots (Table 1). Total woody plant cover did not differ among winter and winter-summer burned plots. Honey mesquite, wolfberry (Lycium berlandieri Dunal), twisted acacia (Acacia schaffneri S. Wats.), Texas persimmon (Diospyros texana Scheele), lotebush [Ziziphus obtusifolia (Hook.) T. \& G.], desert yaupon (Schaefferia cuneifolia Gray), coma [Sideroxylon celastrinum (Kunth) Penn.], and tasajillo (Opuntia lep- tocaulis Cand.) canopy cover was greatest on nonburned plots. Spiny hackberry cover was greatest on nonburned and winter-summer burn plots. Guayacan (Guajacum angustifolium Engelm.) cover was greatest on nonburned plots, which did not differ from winter-summer burned plots. Canopy cover of narrowleaf forestiera (Forestiera angustifolia Torr.) was greatest on nonburned plots, which did not differ from winter burned plots. Lime pricklyash canopy cover was highest on winter burned plots. Density of woody species differed between treatments (MANOVA P $=0.0004$ ). Total woody plant densities varied $(P=0.0077)$ by treatment with nonburned having greater densities than burned plots (Table 2). Density of wolfberry, lotebush, desert yaupon, guayacan, and tasajillo was highest on nonburned plots. Spiny hackberry and Texas pricklypear (Opuntia engelmannii Salm-Reif.-Dyck) density was highest on nonburned plots, which did not differ from winter-summer burned plots.
Density of narrowleaf forestiera was greatest on nonburned plots, which did not differ from winter burned plots. Density of whitebrush [Aloysia gratissima (Gill. \& Hook.) Tron.] was greatest on winter burned and nonburned plots. Frequency of occurrence values varied between treatments (MANOVA P $=0.0080$ ) and followed similar trends as density estimates with the exception of lime pricklyash, Texas pricklypear, whitebrush, and spiny hackberry (Table 3 ). Lime pricklyash was most commonly encountered on winter burned plots; Texas pricklypear had greatest frequency of occurrence on wintersummer burned and nonburned plots; whitebrush was most common on nonburned plots, which did not differ from winter burned plots; and spiny hackberry did not differ among treatments.

\section{Discussion}

Our results indicate that combinations of dormant and growing-season burning of South Texas rangelands can effectively reduce woody plant cover and decrease certain woody plant densities. It should be noted that rangeland fire in southern Texas typically produces a mosaic of burned and nonburned areas as a result of uneven fuel loads (Box and White 1969), and the $100 \%$ coverage by fire on our study sites may not be typical of large-scale application of prescribed fire in much of South Texas. As edaphic characteristics can influence fire effects (Hansmire et al. 1988), care should be exercised when extrapolating these results to other soil types in South Texas. Prescribed burning studies conducted on clay soils in southern Texas (Box et al. 1967, Box and White 1969) are the most in-depth studies upon which regional comparisons can be made. Our observed declines in many woody species following fire were similar to those reported by Box et al. (1967) and Box and White (1969); however, Box et al. (1967) also reported decreases in brasil following September burns, which did not concur with the results of this study. The lack of a reduction of some woody species may be a result of less fuel load and variation in soil type or differences in grazing practices. Fuel loads on rangelands along the transition zone between the South Texas Plains and Gulf Prairies and Marshes can exceed $5,476 \mathrm{~kg} / \mathrm{ha}$ (Hansmire et al. 1988), which can produce more intense fires (Stinson and Wright 1969, Britton and Wright 1971) and possibly higher top-kill and mortality of woody species. 
Table 3. Frequency (\%) on winter burned ${ }^{1}$, winter-summer burned ${ }^{2}$, and nonburned sites $^{3}$ on the Chaparral Wildlife Management Area, Dimmit and La Salle Counties, Tex. 2001.

\begin{tabular}{|c|c|c|c|}
\hline Species & Winter burn & Winter-summer burn & Nonburned \\
\hline & \multicolumn{3}{|c|}{$\ldots \ldots \ldots \ldots(\%)-\ldots \ldots$} \\
\hline Guajillo & $1 \mathrm{a}^{4}$ & Oa & $0 \mathrm{a}$ \\
\hline Catclaw Acacia & $12 \mathrm{a}$ & $4 a$ & $3 a$ \\
\hline Huisache & $1 \mathrm{a}$ & $0 \mathrm{a}$ & $2 \mathrm{a}$ \\
\hline Blackbrush & $4 \mathrm{a}$ & $0 \mathrm{a}$ & $0 \mathrm{a}$ \\
\hline Twisted Acacia & $36 \mathrm{a}$ & $24 \mathrm{a}$ & $39 \mathrm{a}$ \\
\hline Whitebrush & $4 \mathrm{ab}$ & $0 \mathrm{a}$ & $11 b$ \\
\hline Goatbush & $0 \mathrm{a}$ & $0 \mathrm{a}$ & $1 \mathrm{a}$ \\
\hline Sugar Hackberry & $0 \mathrm{a}$ & $0 \mathrm{a}$ & $1 \mathrm{a}$ \\
\hline Spiny Hackberry & $24 a$ & $29 a$ & $33 a$ \\
\hline Hog-plum & $67 \mathrm{a}$ & $57 \mathrm{a}$ & $58 \mathrm{a}$ \\
\hline Brasil & $29 a$ & $19 a$ & $27 \mathrm{a}$ \\
\hline Texas Persimmon & $17 \mathrm{a}$ & $27 \mathrm{a}$ & $26 a$ \\
\hline Vine Ephedra & $0 \mathrm{a}$ & la & $1 \mathrm{a}$ \\
\hline Narrowleaf Forestiera & $3 a b$ & $0 \mathrm{a}$ & $9 b$ \\
\hline Guayacan & $1 \mathrm{a}$ & 1a & $16 b$ \\
\hline Tatalencho & 1a & $0 \mathrm{a}$ & $1 \mathrm{a}$ \\
\hline Leatherstem & $1 \mathrm{a}$ & $2 \mathrm{a}$ & $7 \mathrm{a}$ \\
\hline Coyotillo & $9 a$ & $3 a$ & $13 \mathrm{a}$ \\
\hline Veinyleaf Lantana & $1 \mathrm{a}$ & $0 \mathrm{a}$ & $0 \mathrm{a}$ \\
\hline Common Lantana & $55 a$ & $62 a$ & $59 a$ \\
\hline Wolfberry & $5 a$ & $3 a$ & $19 b$ \\
\hline Texas Pricklypear & $76 a$ & $91 b$ & $91 b$ \\
\hline Tasajillo & $7 \mathrm{a}$ & $7 \mathrm{a}$ & $44 b$ \\
\hline Honey Mesquite & $51 \mathrm{a}$ & $51 \mathrm{a}$ & $57 \mathrm{a}$ \\
\hline Little-leaf Sumac & 1a & $0 \mathrm{a}$ & $1 \mathrm{a}$ \\
\hline Desert Yaupon & $2 \mathrm{a}$ & $3 a$ & $12 b$ \\
\hline Coma & $7 \mathrm{a}$ & $2 \mathrm{a}$ & $5 \mathrm{a}$ \\
\hline Lime Pricklyash & $11 \mathrm{a}$ & $1 b$ & $2 b$ \\
\hline Lotebush & $5 a$ & $6 a$ & $13 b$ \\
\hline
\end{tabular}

${ }_{1}^{1}$ Sites burned during winter 1997-1998 and winter 1999-2000.

${ }^{2}$ Sites burned during winter 1997-1998 and summer 1999.

$\mathrm{n}=15$ transects/site/treatment.

${ }^{4}$ Frequency values for a species across treatments followed by the same letter are not significantly different $(\mathrm{P}>0.05)$.

Reductions of diversity on winter-summer burned plots compared to nonburned plots may not accurately reflect actual responses to fire. Shannon's index of species diversity was considerably lower on 1 winter-summer burned plot compared to the other 4 replications. This may reflect pretreatment differences among plots prior to burning. Previous vegetation mapping (Gabor 1997) suggested that all study plots were similar in regards to dominant woody species and total woody plant canopy cover before application of burning treatments; however, pretreatment differences in species composition, especially less common (frequency of occurrence < $15 \%)$ species may have existed. With the exception of lime pricklyash, declines in woody plants were limited to burned plots suggesting that declines were a result of the burning treatments. Sample sizes may also have been inadequate to fully assess treatment effects on uncommon species such as lime pricklyash.

Management of mesquite (Prosopis spp. L.) is a primary concern of range managers throughout the southwestern United States and northern Mexico. Mesquite can be significantly reduced following fire (Box and White 1969, Wright et al. 1976, Cable 1965). Mesquite cover declined on both burning treatments but fire did not appear to induce significant mortality. As with other woody species, moderate and uneven fuel loads coupled with varying fire behavior may have produced less intense fires resulting in low mortality. Our results were similar to Heirman and Wright (1973) in which living mesquites were not killed following prescribed burns in west Texas with fuel loads similar to our study. Wood boring insect infestations may increase in trees damaged by fire facilitating burndown and mortality as a result of secondary burns (Ueckert and Wright 1974). It is unclear to what degree wood boring insects may have infested honey mesquite following initial burns; however, little honey mesquite burndown was observed during secondary fire applications. Crown sprouting by mesquite following fire is greatest in trees that exceed $5-\mathrm{cm}$ in stem diameter (Cable 1965). Although not quantified, stem diameter of most honey mesquite on our study sites appear to exceed $5-\mathrm{cm}$ resulting in the maintenance of some form of apical dominance. The lack of top-kill may have reduced basal sprouting leading to the observed maintenance of canopy cover reductions 2 years following the last burn application.

Cacti (Opuntia spp. Miller) can also be a concern of livestock and wildlife managers. While cacti are an important food source for species such as white-tailed deer (Arnold and Drawe 1979) and javelina (Tayassu tajacu L.) (Sowls 1997), large colonies of Texas pricklypear can result in extensive areas virtually devoid of herbaceous vegetation. The high susceptibility of tasajillo to fire was similar to other studies (Box et al. 1967, Box and White 1969, Bunting et al. 1980). Brownspine pricklypear (Opuntia phaeacantha Engelm.) suffers little direct mortality following burning (Heirman and Wright 1973, Bunting et al. 1980); however, tissue destruction caused by burning increases vulnerability to damage from insects, rodents, and lagomorphs which can result in high mortality 2-3 years following burns. Moderate fuel loads combined with the robust growth form of Texas pricklypear in South Texas may explain it's general resilience to fire and subsequent insect damage. Reductions of Texas pricklypear densities on winter burned plots may in part be a result of herbivory by cattle. Texas pricklypear can be an important portion of cattle diet during winter (Everitt et al. 1981). Cattle were allowed access to pastures in which burned plots were located immediately following winter burns. Cattle readily browsed freshly burned Texas pricklypear and observations were made in which the entire above ground biomass of some plants was consumed.

Winter burns were effective in reducing canopy cover of spiny hackberry, which was similar to responses observed in the transition zone between the South Texas Plains and Gulf Prairies and Marshes (Box et al. 1967). Spiny hackberry appears to survive most fire damage but recovery rates of top-growth are slower than many other woody species. Slow recovery rates may be compounded through herbivory by white-tailed deer and other herbivores. Top-removal of woody species can increase nutrient content of regrowth (Everitt 1983), which may increase utilization by herbivores (Rasmussen et al. 1983). Spiny hackberry and other woody plants such as guayacan, which declined following burns, are considered highly preferred browse of white-tailed deer (Taylor et al. 1997). Deer density on the study area during the duration of the study 
Appendix Table 1. Scientific and common names of woody species.

\begin{tabular}{|c|c|}
\hline Scientific name $^{1}$ & Common Name ${ }^{2}$ \\
\hline Acacia berlandieri Benth. & Guajillo \\
\hline Acacia greggii Gray & Catclaw Acacia \\
\hline Acacia minuata $\mathrm{M}$. Jones & Huisache \\
\hline Acacia rigidula Benth. & Blackbrush \\
\hline Acacia schaffneri S. Wats. & Twisted Acacia \\
\hline Aloysia gratissima (Gill. \& Hook.) Tron. & Whitebrush \\
\hline Castela erecta (Turpin) T. \& G. & Goatbush \\
\hline Celtis laevigata Willd. & Sugar Hackberry \\
\hline Celtis pallida Torr. & Spiny Hackberry \\
\hline Colubrina texensis (T. \& G.) Gray & Hog-plum \\
\hline Condalia hookeri M. C. Johnst. & Brasil \\
\hline Diospyros texana Scheele & Texas Persimmon \\
\hline Ephedra antisyphilitica (Berl.) Meyer & Vine Ephedra \\
\hline Forestiera angustifolia Torr. & Narrowleaf Forestiera \\
\hline Guajacum angustifolium Engelm. & Guayacan \\
\hline Gymnosperma glutinosum (Spreng.) Less. & Tatalencho \\
\hline Jatropha diocia Cerv. & Leatherstem \\
\hline Karwinskia humboltiana (Schult.) Zucc. & Coyotillo \\
\hline Lantana achyranthifolia Desf. & Veinyleaf Lantana \\
\hline Lantana urticoides Hayek & Common Lantana \\
\hline Lycium berlandieri Dunal & Wolfberry \\
\hline Opuntia engelmannii Salm-Reif.-Dyck & Texas Pricklypear \\
\hline Opuntia leptocaulis Cand. & Tasajillo \\
\hline Prosopis glandulosa Torr. & Honey Mesquite \\
\hline Rhus microphylla (Engelm.) Gray & Little-leaf Sumac \\
\hline Schaefferia cuneifolia Gray & Desert Yaupon \\
\hline Sideroxylon celastrinum (Kunth) Penn. & Coma \\
\hline Zanthoxylum fagara (L.) Sarg. & Lime Pricklyash \\
\hline Ziziphus obtusifolia (Hook.) T. \& G. & Lotebush \\
\hline
\end{tabular}

${ }_{1}^{1}$ Jones et al. (1997)

${ }^{2}$ Hatch et al. (1990)

averaged one adult deer $18 \mathrm{ha}^{-1}$ year $^{-1}$, which we consider below carrying capacity for these rangeland sites. It is unclear to what degree herbivores such as whitetailed deer, lagomorphs, rodents, and arthropods may have impacted regrowth of woody plants following fires.

Woody plants comprise a very small portion of cattle diet in South Texas (Everitt et al. 1981) and direct impacts of cattle grazing appear to have little impact on woody plants following fire. High intensity, low frequency grazing results in greater consumption of less-preferred forage species (Drawe 1988), which can lead to the more uniform grazing of herbaceous plants. The high intensity, low frequency grazing system employed during the dormant-season on the study area appears to reduce selective grazing and minimize any effects selective grazing pressure may have on competition between woody and herbaceous plants following fire. Deferment of grazing on the study area during the majority of the growing-season may however, increase competition between herbaceous and woody plants.

Competition among woody plants may also explain reductions in spiny hackberry and other woody plants. Declining species such as spiny hackberry, lotebush, Texas pricklypear, tasajillo, wolfberry, and periods of high soil moisture and may have resulted in cooler burning conditions and less cambium destruction.

Three common (frequency $\geq 25 \%$ ) woody plants that appeared highly adapted to fire are twisted acacia, hog-plum, and common lantana (Lantana urticoides Hayek). These species are generally low growing shrubs and because of litter accumulations beneath plants, especially hogplum and common lantana, are easily topkilled following fire. Observations were made in which top growth of many hogplum and common lantana plants were entirely consumed by fires. Twisted acacia and hog-plum are most abundant in the interspace between honey mesquite-shrub clusters, whereas lantana (Lantana spp. L.) is associated with honey mesquite clusters (Whittaker et al. 1979, Archer et al. 1988). Lack of competition between twisted acacia and hog-plum and other woody plants may explain their ability for rapid recovery following fire, while common lantana appears to more effectively compete with other woody plants within clusters. The response of twisted acacia to fire was comparable to that of huisache (Acacia minuata M. Jones) (Rasmussen et al. 1983), which tends to be replaced by twisted acacia along the decreasing east to west precipitation gradient across the South Texas Plains.

desert yaupon are closely associated with honey mesquite clusters (Whittaker et al. 1979, Archer 1989). Mesquite clusters result in concentrations of woody plants relative to the interspace between clusters. Brasil, which is also a common component of shrub clusters and demonstrated little decline following fires, appears to be more efficient in competing with other woody plants within clusters. Fire increases productivity of herbaceous plants, especially forbs on South Texas rangelands (Hansmire et al. 1988, Ruthven et al. 2000), and increased competition between woody and herbaceous plants may also account for reductions of woody plants on burned plots.

Summer fire applied during periods of above normal soil moisture can result in less damage and subsequent decline of woody plants compared to dormant-season fire applied under low soil moisture conditions (Adams et al. 1982). In part, reductions of spiny hackberry and Texas pricklypear on winter burn treatments may be explained by soil moisture conditions at the time of burning. All winter burns were conducted under relatively dry conditions, which may have resulted in high temperatures at and just below the soil surface causing greater internal tissue damage. Summer burns were performed during

\section{Conclusions and Management Implications}

Both burning treatments were effective at reducing honey mesquite cover, which may promote the observed increases in herbaceous vegetation following fire on South Texas rangelands (Hansmire et al. 1988, Scifres and Hamilton 1993). Summer burning following significant rainfall may be effective in managing honey mesquite, while maintaining desirable woody species such as spiny hackberry. If reducing total woody plant cover is a management goal, burning during winter following periods of little or no rainfall is recommended. Further investigation into the response of woody plants to summer fire under various environmental conditions, in particular, low soil moisture is necessary to fully evaluate the effects of summer fire on woody plants. Where feasible, prescribed burning can manage woody vegetation without dramatic reduction in woody plant diversity, which is common with many traditional mechanical treatments (Fulbright and Beasom 1987, Ruthven et al. 1993). 
If managing South Texas rangelands for white-tailed deer is a desired goal, it may be beneficial to limit the use of fire in areas dominated by highly preferred species which decline following fire and target areas dominated by vulnerable less desired species and desirable fire-tolerant species. Woody plant species such as twisted acacia and common lantana, which recover quickly following fire, are not generally considered important forage species for white-tailed deer (Arnold and Drawe 1979, Taylor et al. 1997), whereas hog-plum can be a preferred browse plant (Arnold and Drawe 1979, Ruthven et al. 1994). Although less desirable browse species such as honey mesquite, wolfberry, and desert yaupon decline following fire, the importance of these species to other game and nongame wildlife is not well documented. The effects of the structural changes of woody plant communities following fire on nongame wildlife warrant further investigation.

We recommend that initial burns on native South Texas rangelands be conducted on a 2-year interval until the desired structure of woody vegetation is achieved. Once desired goals are met, maintenance burning on a 3-5 year frequency may be adequate. Grazing strategies that allow for substantial deferment to produce adequate fuels to carry fire are critical to the successful application of fire on South Texas rangelands. High intensity, low frequency grazing systems, such as that employed on the study area, appear to be the most compatible for the incorporation of fire into a management program (Drawe 1988). Other considerations to be taken into account are the highly unpredictable weather patterns in South Texas. Shortterm periods of drought are common and rainfall can be highly variable between locations (Norwine and Bingham 1985). Drought can severely impact production of fine fuels necessary to carry fire and may require flexibility in burning schedules.

Honey mesquite and associated woody plants dominate rangelands throughout South Texas; yet, productivity and species composition of herbaceous plant communities can vary greatly along the decreasing east to west precipitation gradient across the region. Decreases in herbaceous vegetation may increase the utilization of woody plants by herbivores. Further research into the interaction between burning and herbivory is needed to fully assess the effects of fire and its use as a management tool on South Texas rangelands.

\section{Literature Cited}

Adams, D.E, R.C. Anderson, and S.L. Collins. 1982. Differential response of woody and herbaceous species to summer and winter burning in an Oklahoma grassland. Southwest. Nat. 27:55-61.

Archer, S. 1989. Have southern Texas savannas been converted to woodlands in recent history? Amer. Nat. 134:545-561.

Archer, S. 1994. Woody plant encroachment into southwestern grasslands and savannas: rates, patterns and proximate causes, $\mathrm{p}$ 13-68. In: M. Vavra et al. (eds.) Ecological implications of livestock herbivory in the west. Society for Range Management, Denver, Colo.

Archer, S., C. Scifres, C.R. Bassham, and R. Maggio. 1988. Autogenic succession in a subtropical savanna: conversion of grassland to thorn woodland. Ecol. Monogr. 58:111-127.

Arnold, L.A. and D.L. Drawe. 1979. Seasonal food habits of white-tailed deer in the south Texas plains. J. Range Manage. 32:175-178.

Box, T.W. and R.S. White 1969. Fall and winter burning of south Texas brush ranges. J. Range Manage. 22:373-376.

Box, T.W., J. Powell, and D.L. Drawe. 1967. Influence of fire on south Texas chaparral communities. Ecol. 48:955-960.

Britton, C.M. and H.A. Wright. 1971. Correlation of weather and fuel variables to mesquite damage by fire. J. Range Manage. 24:136-141.

Bunting, S.C., H.A. Wright, and L.F. Neuenschwander. 1980. Long-term effects of fire on cactus in the southern mixed prairie of Texas. J. Range Manage. 33:85-88.

Burrow, A.L, R.T. Kazamier, E.C. Hellgren, and D.C. Ruthven, III. 2001. Microhabitat selection by Texas horned lizards in southern Texas. J. Wildl. Manage. 65:645-652.

Cable, D.R. 1965. Damage to mesquite, Lehmann lovegrass, and black grama by a hot June fire. J. Range Manage. 18:326-329.

Canfield, R.H. 1941. Application of line interception in sampling range vegetation. $\mathrm{J}$. Forest. 39:388-394.

Drawe, L. D. 1988. Effects of three grazing treatments on vegetation, cattle production, and wildlife on the Welder Wildlife Foundation Refuge, 1974-1982. Welder Wildl. Foundation Contribution B-8, Sinton, Tex.

Everitt, J.H. 1983. Effects of plant shredding on nutrient content of four south Texas deer browse species. J. Range Manage. 36:779-781.

Everitt, J.H., C.L. Gonzales, G. Scott, and B.E. Dahl. 1981. Seasonal food preferences of cattle on native range in the south Texas plains. J. Range Manage. 34:384-388.

Fair, W.S. and S.E. Henke. 1997. Effects of habitat manipulations on Texas horned lizards and their prey. J. Wildl. Manage. 61:1366-1370.
Fulbright, T.E. and S.L. Beasom. 1987. Long-term effects of mechanical treatments on white-tailed deer browse. Wildl. Soc. Bull. 15:560-564.

Gabor, T. 1997. Ecology and Interactions of sympatric collared peccaries and feral pigs. Ph.D. Diss., Oklahoma State Univ., Stillwater, Okla.

Gabriel, W.J., D Arriaga, and J.W. Stevens. 1994. Soil survey of LaSalle County, Texas. USDA. Wahington, D.C.

Guthery, F.S. 1986. Beef, brush and bobwhites: quail management in cattle country. Golden Banner Press, Inc., Corpus Christi, Tex.

Hansmire, J.A., D.L. Drawe, D.B. Wester, and C.M. Britton. 1988. Effects of winter burns on forbs and grasses of the Texas Coastal Prairie. Southwest. Nat. 33:333-338.

Hatch, S.L., K.N. Gandhi, and L.E. Brown. 1990. Check list of the vascular plants of Texas. Tex. Agr. Exp. Sta. Misc. Pub. MP1655.

Heirman, A.L. and H.A. Wright. 1973. Fire in medium fuels of West Texas. J. Range Manage. 26:331-335.

Jones, S.D., J. K. Wipff, and P. M. Montgomery. 1997. Vascular plants of Texas. Univ. Texas Press, Austin, Tex.

Kazmaier, R T. 2000. The effects of grazing on ecology and demography of the Texas tortoise (Gopherus berlandieri) in the western Rio Grande Plains. Ph.D. Diss., Oklahoma State Univ., Stillwater, Okla.

Lehmann, V.W. 1969. Forgotten legions: sheep in the Rio Grande Plain of Texas. Texas Western Press, El Paso, Tex.

McLendon, T. 1991. Preliminary description of the vegetation of south Texas exclusive of coastal saline zones. Tex. J. Sci. 43:13-32.

Norwine, J. and R. Bingham. 1985. Frequency and severity of drought in south Texas, p. 1-19 In: R. Brown (ed.) Livestock and wildlife management during drought. Caesar Kleberg Wildlife Research Institute, Kingsville, Tex.

Pielou, E.C. 1975. Ecological diversity. John Wiley \& Sons, New York, N.Y.

Rasmussen, G.A., C.J. Scifres, and D.L. Drawe. 1983. Huisache growth, browse quality, and use following burning. J. Range Manage. 36:337-342.

Ruthven, D.C., III, J.F. Gallagher, and D.R. Synatzske. 2000. Effect of fire and grazing on forbs in the western south Texas plains. Southwest. Nat. 445:89-94.

Ruthven, D.C., III, E.C. Hellgren, and S.L. Beasom. 1994. Effects of root plowing on white-tailed deer condition, population status, and diet. J. Wildl. Manage. 58:59-70.

Ruthven, D.C.III, T.E. Fulbright, S.L. Beasom, and E.C. Hellgren. 1993. Longterm effects of root plowing on vegetation in the eastern south Texas plains. J. Range Manage. 46:351-354.

Scifres, C.J. and K.W. Duncan. 1982. Brownseed paspalum response to season of burning. J. Range Manage. 35:251-253. 
Scifres, C.J. and W.T. Hamilton. 1993. Prescribed burning for brushland management: the south Texas example. Texas A\&M University Press, College Station, Tex.

Sowls, L.K. 1997. Javelinas and other peccaries: their biology, management, and use Texas A\&M University Press, College Station, Tex.

Stevens, J.W. and D. Arriaga. 1985. Soil survey of Dimmit and Zavala Counties, Texas. USDA. Wahington, D.C.

Stinson, K.J. and H.A. Wright. 1969. Temperature of headfires on the southern mixed prairie of Texas. J. Range Manage. 22:169-174.
Taylor, R.B., J. Rutledge, and J.G. Herrera 1997. A field guide to common south Texas shrubs. Texas Parks and Wildlife Press, Austin, Tex.

Ueckert, D.N. and H.A. Wright. 1974. Wood boring insect infestations in relation to mesquite control practices. J. Range Manage. 27:383-386.

Whittaker, R.H., L.E. Gilbert, and J.H Connell. 1979. Analysis of two-phase pattern in a mesquite grassland, Texas. J. Ecol. 67:935-952.
Wilkins, N., R.D. Brown, R.J. Conner, J. Engle, C. Gilliland, A. Hays, R.D. Slack, and D.W. Steinbach. 2000. Fragmented lands: changing land ownership in Texas. Texas A\&M Univ, Agr. Commun. Pub. MKT-3443, College Station, Tex.

Wright, H.A. and A.W. Bailey. 1982. Fire Ecology. John Wiley and Sons, New York, N.Y..

Wright, H.A., S.C. Bunting, and L.F. Neuenschwander. 1976. Effects of fire on honey mesquite. J. Range Manage. 29:467-471 